\title{
Islamic Financial Literacy in Mathematics Education: Proposed Design for Instruction
}

\author{
Intan B. Kusumawati ${ }^{1, *}$ Achmad D. Fachrudin ${ }^{1}$ Ratu I. I. Putri ${ }^{2}$ Zulkardi Zulkardi ${ }^{2}$ \\ Soffil Widadah ${ }^{1}$ Muhammad K. Mubarok ${ }^{1}$
}

\author{
${ }^{1}$ STKIP PGRI Sidoarjo, Indonesia \\ ${ }^{2}$ Universitas Sriwijaya Palembang, Indonesia \\ *Corresponding author.Email: bigita.intan@gmail.com
}

\begin{abstract}
This study aims to develop a social arithmetic learning design by integrating Islamic economic principles. Using various Islamic financial products as a context in mathematical tasks, we propose a hypothetical learning trajectory (HLT) to support the students' Islamic financial literacy (IFL) skills. We chose design research as the method to achieve the goal. However, we limit the discussion to a part of one phase, namely pilot experiments, of the three main phases of design research. This study involves six students at Islamic junior high school. The design consists of several activities that require students to solve mathematics-based Islamic financial literacy tasks. These tasks contain IFL knowledge, including money and shariah transaction, planning and managing finance using shariah product, risk, and reward of shariah finance product, and a landscape of shariah finance. We develop an instructional design by adapting the process domain of the OECD financial literacy by adjusting based on the principles of Islamic economics. In general, the stages of learning activities are identifying Islamic financial information, analyzing information in an Islamic financial context, and applying Islamic financial knowledge and understanding. At each of these stages, students are faced with problems that focus on each process domain. The results show that this design can bring out some fundamental mathematical capabilities and support the students' IFL. Furthermore, by infusing Islamic financial literacy in mathematics education, we get an opportunity to create a caring young generation on the development of Indonesian Islamic economics.
\end{abstract}

Keywords: Islamic financial literacy, Mathematics education, Design research.

\section{INTRODUCTION}

Recommendations to include financial education in mathematics education have been emphasized by several researchers [1,2]. The relationship and linkage between mathematical concepts and financial literacy are also presented by the OECD [3] in the PISA assessment and analytical framework, namely the basic arithmetic content that requires students to apply knowledge in the context of everyday financial problems. Several countries have explicitly integrated financial literacy into the achievement of the mathematics education curriculum $[2,4]$. This fact shows that financial understanding can be constructed through mathematics education. Furthermore, [3] asserted that financial literacy skills have a high correlation with mathematical literacy. Students with high math literacy scores tend to have high financial literacy scores and vice versa.
Considering Indonesia's mathematics education curriculum, an understanding of financial issues has been taught, although it is limited to calculating bank interest on social arithmetic material. However, when referring to the demands for understanding financial literacy based on the assessment framework from PISA [3], the demands for learning outcomes in the Indonesian curriculum are still far from sufficient. Moreover, financial education is not provided separately from formal education.

In Indonesia, financial literacy does not mean only conventional financial literacy but also Islamic financial literacy. It is known that the Indonesian government implements the Islamic economic system along with the conventional system. In addition, the government also has the Islamic economic development program designed by Bank Indonesia (BI). One of these programs is strengthening the Islamic economy, which involves the economic 
independence of Islamic boarding schools. This reinforces the importance of integrating Islamic financial literacy in formal education, especially in Islamic boarding schools. On the other hand, [5] stressed that Islamic economics is important to be introduced in basic education at the secondary school level in Islamic schools. The lack of research and support for the development of learning designs or learning tools on integrating the concept of Islamic Economics in mathematics education is our current concern. We conclude that developing an integrated mathematics learning design with Islamic economic principles to promote students' IFL will make a major contribution to mathematics teachers in Islamic boarding schools.

It is known that not all aspects of IFL are in line with mathematical concepts. Therefore, by considering the compatibility between mathematics concepts, financial literacy, and Islamic economics, we provide boundaries for the IFL domain that intersects with mathematics education. We developed a framework of conformity between these three aspects and named it the mathematics-based Islamic financial literacy (MIFL) framework [6]. We developed the framework by referring to the content domain of the OECD [3] PISA financial literacy framework. For conformity with the mathematical concept, we chose 'social arithmetic' material, which is material that has room to be integrated with IFL based on the current curriculum. Meanwhile, on the Islamic economic aspect, we refer to the opinion of Nawi [7], which limits that IFL is related to Islamic banking products. Therefore, we limit the framework to several contexts of banking products with mudharabah, musyarakah, and murabahah contracts. Using the context of the Islamic banking product, we compiled a mathematical assignment based on the framework. We use the MIFL framework-based math assignments to develop learning designs and assessments to assess students' IFL abilities.

Referring to the OECD process domain financial literacy [3], in this study, we develop a series of social arithmetic learning activities that are integrated with Islamic financial literacy. At each stage of the learning activity, we provide mathematical tasks based on the MIFL framework. The development of these activities is arranged using a designbased research method [8] by developing a hypothetical learning trajectory.

\section{ISLAMIC FINANCIAL LITERACY IN MATHEMATICS EDUCATION}

Numerous studies reveal that problem situations or context play an important role in learning mathematics, especially in helping students develop mathematical concepts $[9,10]$. Many problem situations can be brought into mathematics learning, one of which is the financial problem. For example, Yeo brings the context of financial literacy into mathematics learning by creating a mathematical task framework integrated with the content of financial literacy knowledge. Meanwhile, [2] develops mathematics learning that involves financial dilemmas to promote students' financial literacy. Then, Bringing Islamic finance problems also provides opportunities to improve students' understanding and the quality of learning in social arithmetic.

In bringing Islamic financial literacy into mathematics education, we have developed a framework that is used to determine the achievement of Islamic financial literacy regarding mathematics education. We refer to the OECD [3] content domain of financial literacy to develop the MIFL framework. By referring to several studies on IFL [7,11], we outline some contexts of IFL issues relevant to the junior high school curriculum. We have discussed the development of this framework in another paper that also involves an expert review. There are 4 content domains of MIFL capabilities that we define (Fig 1). The framework developed is used as a guide in developing mathematical tasks that mediate the integration of Islamic financial literacy into mathematics education. The framework articulates a schema on a mathematical concept with the appropriate category of Islamic financial literacy [6].

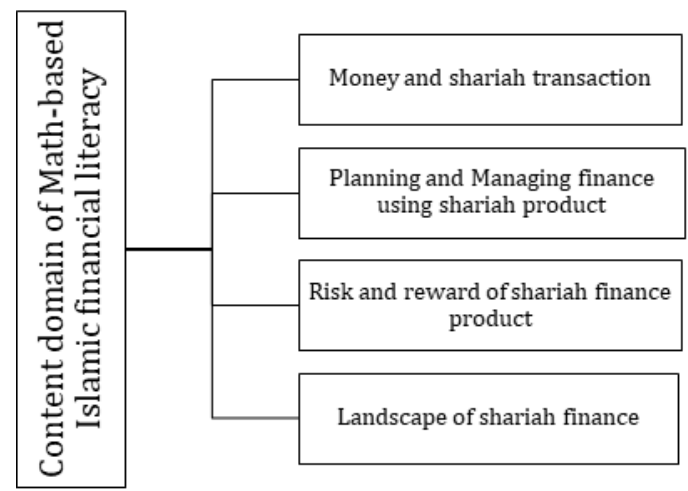

Figure 1 The content domain of Math-based Islamic financial literacy (MIFL).

On the other hand, in developing the learning sequence we adapted the process domain of the OECD [3] (Fig. 2) financial literacy framework. By adjusting to the product context in Islamic banking, we develop three main processes that are realized into three stages of learning activities. We provide a more detailed of the learning activities in the results and discussion section.

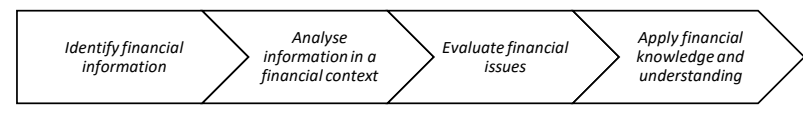

Figure 2 OECD financial literacy process domain.

\section{METHODS}

We use the design research method to develop a series of social arithmetic learning activities that are integrated with Islamic financial literacy. This study aims to develop Local Instruction Theory (LIT) [12] by testing the Hypothetical Learning Trajectory (HLT) as an initial design with actual learning. We carried out the testing through the pilot experiment stage and teaching experiment stage. However, 
we limit our discussion to pilot experiments of the three main phases of design research.

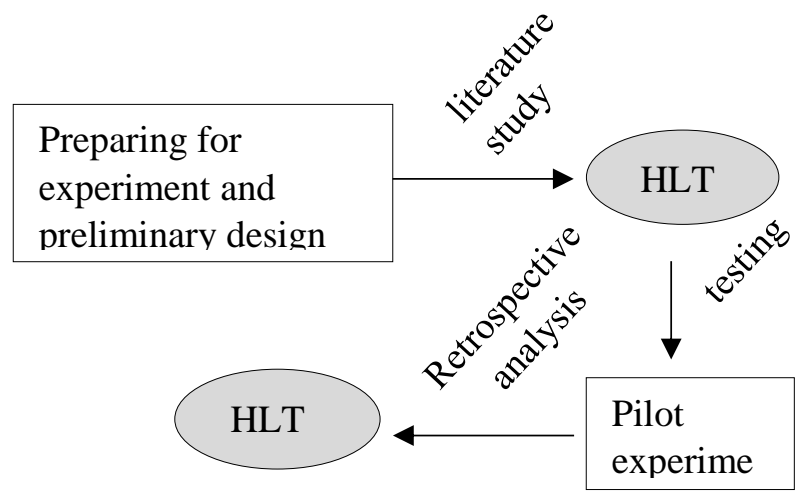

Figure 3 The research method.

In stage preparing for experiments, we developed a mathematics-based Islamic financial literacy framework, designed mathematical tasks based on the framework, and developed HLT.

This study involved six students as research subjects. The data collected are field notes and student work. After conducting HLT testing, we performed a retrospective analysis to compare actual learning trajectory (ALT) and HLT. We use the results of the analysis to improve the HLT. We conducted the HLT analysis at the pilot experiment stage using task-oriented analysis (Table 1), referring to [8]. By looking at student achievement on each task in each activity, we can improve at each stage and determine the extent to which teacher assistance is needed. In addition, by comparing HLT and ALT, we can find out which part of the task requires revision and improvement according to the level of student understanding.

Table 1. Matrix data analysis for comparing HLT and actual learning trajectory (ALT) [8]

\begin{tabular}{|l|l|l|}
\hline \multicolumn{2}{|l|}{ Hypothetical learning trajectory } \\
\hline Task number & $\begin{array}{l}\text { Formulating } \\
\text { of the task }\end{array}$ & $\begin{array}{l}\text { Conjecture of } \\
\text { students' thinking }\end{array}$ \\
\hline Actual learning trajectory \\
\hline $\begin{array}{l}\text { Transcript } \\
\text { excerpt }\end{array}$ & Clarification & $\begin{array}{l}\text { Match between HLT } \\
\text { and ALT }\end{array}$ \\
\hline
\end{tabular}

\section{RESULT AND DISCUSSION}

\subsection{The Learning Sequence of HLT}

In this section, we will briefly describe the learning activities on the HLT that we have developed. The developed learning activities are adapted from the process domain of the OECD framework in solving financial literacy problems. However, we made adjustments to the use of content related to Islamic financial mathematics and the context of Islamic banking. The following is a brief overview of the learning activities we organized (Fig. 4). The sequence of the learning in each activity is the observation of the initial problem, material presentation, exploration, and exercise.

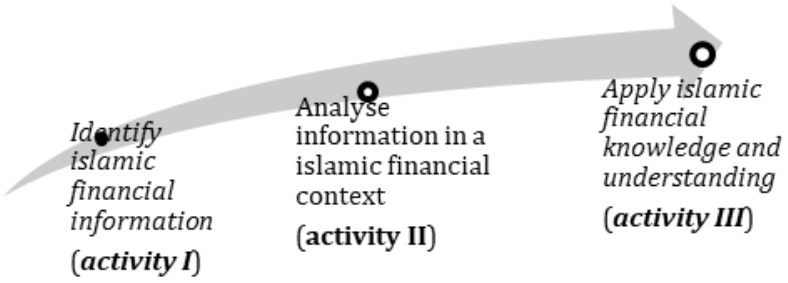

Figure 4 Learning activities in the learning sequence.

\section{Activity I}

In the first activity, students were given arithmetic problems related to understanding information on Islamic bank transactions. The purpose of this activity is that students can understand the information and calculations of financial transactions that arise from various contracts and their calculations in the context of Islamic finance. In this activity, students will learn to understand the mathematical concepts involved in understanding Islamic financial transactions. The following that shown in figure 5 is one of the problems of the money and sharia transaction content domain that we gave to students in the first activity.

Mr. Fulan is a customer of Bank Syariah Indonesia (BSI). The following is his list of account mutations for two months.

\begin{tabular}{|c|c|c|c|c|}
\hline Date & $\begin{array}{c}\text { Transaction } \\
\text { Details }\end{array}$ & $\begin{array}{c}\text { Credit } \\
\text { (IDR) }\end{array}$ & $\begin{array}{c}\text { Debit } \\
\text { (IDR) }\end{array}$ & $\begin{array}{c}\text { Balance } \\
\text { (IDR) }\end{array}$ \\
\hline $3 / 2 / 20$ & $\begin{array}{c}\text { Administration } \\
\text { fee }\end{array}$ & & 15,000 & $10,000,000$ \\
\hline $3 / 2 / 20$ & Profit-sharing & 30,000 & & $10,030,000$ \\
\hline $4 / 2 / 20$ & $\begin{array}{c}\text { X Company } \\
\text { January Salary }\end{array}$ & $4,500,000$ & & $14,530,000$ \\
\hline $7 / 2 / 20$ & Withdrawal & & $2,000,000$ & $12,530,000$ \\
\hline $16 / 2 / 20$ & $\begin{array}{c}\text { Transfer Mr. } \\
\text { Fulan 0011 }\end{array}$ & 500,000 & & $12,230,000$ \\
\hline
\end{tabular}

The following is the calculation of profit-sharing for customers.

Customers' profit-sharing $=\frac{\text { Balance }}{1000} \times 6.5 \times$ nisbah

Nisbah $=$ Percentage of profit-sharing for customers

Determine the amount of the nisbah given by BSI to its customers!

Figure 5 Problem in the activity I.

\section{$\underline{\text { Activity II }}$}

In the second activity, students are given arithmetic problems related to information analysis in the context of Islamic finance. The purpose of this activity is that students can analyze information and perform calculations to find out which Islamic financial products are more profitable based on their calculations. The following is a problem that we gave to students in the second activity. The following that shown in 
figure 6 is one of the problems of planning and managing finance using shariah product content domain that we gave to students in the second activity.

Syariah Mandiri Bank offers two types of homeownership credit programs with murabahah contracts. The following is an ad that contains the margin program offered.

Step up program:

$8.50 \%$ per year (for $1 \mathrm{st}-2$ nd year)

$10.5 \%$ per year (for 3 rd -5 th year)

$14 \%$ per year (for 6 th -20 th year)

Single price program:

$10 \%$ per year (for $1-5$ year fixed period)

$11 \%$ per year (for $>5-10$ year fixed period)

$12 \%$ per year (for $>10-15$ year fixed period)

$12.5 \%$ per year (for $>15-20$ year fixed period)

Mr. Zailan plans to buy a house for 200,000,000 IDR and apply for a housing loan to the Syariah Mandiri bank for 15 years in installments. Based on the two programs offered, determine which program is the most profitable for Mr. Zailan!

Figure 6 Problem in activity II.

\section{Activity III}

In the third activity, we gave problems related to applying understanding or taking the most appropriate action in dealing with problems in various Islamic financial contexts based on arithmetic calculations. This process is reflected in tasks that involve solving problems, including performing basic arithmetic and considering various conditions based on the results of these calculations. The following that shown in figure 7 is one of the problems of the landscape of shariah finance content domain that we gave to students in the third activity.

Mr. Fulan is one of the Bank Syariah Indonesia (BSI)
debtors affected by COVID-19 and gets relaxation from
BSI in the form of an additional one-year installment
period.
The following is Mr. Fulan's contract data before the
relaxation policy for customers.
Customer: Mr. Fulan
Financing ceiling : IDR 20,000,000
Bank Margin (per year): $8 \%$
Types of contract: Murabahah financing contracts
Installment period (initial): 4 years
Installment Nominal (per month) IDR 550,000
If Mr. Fulan has fulfilled her installment obligations to
the bank for the previous 24 months, determine the
number of installments per month he must pay for the
remaining period!

Figure 7 Problem in activity III.
We only present three examples of MIFL assignments, but in total there are 6 assignments that we give to students. Our conjecture of student thinking is able to complete the task with a little guidance. Task 1 is in the first activity, task 2 is in the second activity, tasks $3,4,5$, and 6 are in the third activity. The third activity has the most task composition because it is the stage of applying the knowledge of Islamic financial literacy that has been built in the previous two activities.

\subsection{Retrospective Analysis}

In this section, we will briefly describe the results of the HLT implementation test that we have developed compared to ALT. The following shown in table 2 is the result of the comparison between HLT and ALT in the pilot experiment.

Table 2. Actual Learning result compared with HLT conjectures for each task

\begin{tabular}{|c|c|c|c|c|c|c|}
\hline+ & $x$ & & & $x$ & $x$ & \\
\hline \pm & & & $x$ & & & $x$ \\
\hline- & & $x$ & & & & \\
\hline Task & 1 & 2 & 3 & 4 & 5 & 6 \\
\hline
\end{tabular}

Note: an $\mathrm{x}$ means how well the conjecture matched to the observed learning ( - refers to confirmation for up to $1 / 3$ of the total students, and + to at least $2 / 3$ of the total students)

Based on the table above, we know that for the assignment in the first activity, students can complete well. Based on interviews and discussions with teachers, students' difficulties were only found in understanding some terms that were still unfamiliar to students. The following are excerpts of student interviews about words they did not understand.

Teacher: Have you ever studied social arithmetic in the context of Islamic banking?

Khausar: Never.

Teacher: What are the words used in the task that you don't understand?

Khausar: Customer, margin, debit, credit, nisbah (ratio), tenor.

The answers from Khausar represent other students who have the same difficulty related to understanding unfamiliar words. Based on the interview excerpt above, it can be seen that in the first activity, the problems encountered by students were about unfamiliar words in Islamic banking. We overcome this limitation by providing initial material about Islamic banking and discussions. This result is in accordance with the conjecture that we formulated in the first activity. In general, in this first activity, learning focuses on the introduction and assignment to identify Islamic financial information.

In the second activity, which focuses on analyzing information in an Islamic financial context, all students are not able to complete the task correctly (see the task in Fig.6). 
All students made an error in understanding the fix period program of the task. They understand that the fixed period program is the same as the step-up program. The following is an example of student's error that is shown in figure 8.

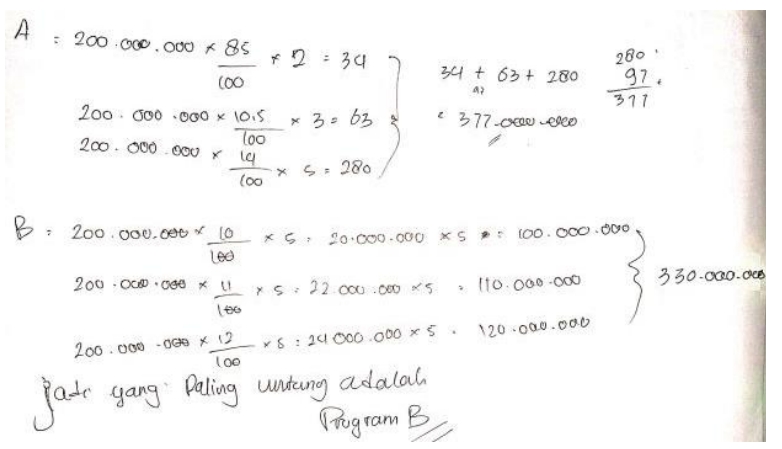

Figure 8 Student's error on task 2.

Based on our analysis, this error is caused by the use of symbols that distinguish between the two programs in the questions that are still confusing for students. Therefore, we will make adjustments to the second task so as not to make students misunderstand the information in the task. We will choose a simpler Islamic financial context to make it understandable for students. Even though it doesn't match our conjecture, we keep this activity by changing the context of the task.

In the third activity, students were presented with several problems that focused on applying Islamic financial knowledge and understanding. in this activity, we gave some tasks in different content domains. In this case, we assign 2 tasks on planning and managing using shariah product content, 1 risk and reward task of shariah finance product, and 1 task on the landscape of shariah finance content. In general, students can complete all of the tasks. This is in accordance with our conjecture. However, based on the field notes collected, students experienced some difficulties when modeling problems into mathematical forms.

In general, the ALT is in accordance with the HLT, although we had to make minor revisions to the assignment in Activity II. In addition, we heard students' suggestions to improve the presentation of pictures and tables on tasks to make it easier for them to understand.

At the end of the lesson, we interviewed students regarding their opinion about the learning design. Here is a snippet of his interview.

Teacher: what is your impression of this MIFL assignment and learning?

Khausar: it makes me happier to study mathematics and it is in accordance with the religious lessons that I am taking at the Islamic boarding school.

Alamsyah: increase my knowledge about calculations related to Islamic banking products.
The interview above indicates that students are interested in learning social arithmetic by involving the context of Islamic finance. Students think that they get new insight at learning mathematics and are interested in it. Learning new things can stimulate students' imagination for modeling the problems. This will make mathematics more meaningful, fun, and useful for students as emphasized by [2]. In addition, many studies confirm that the use of contextual problems will improve students' mathematical abilities [9]. Furthermore, the learning design has a potential effect in bringing out some fundamental mathematical capabilities, including supporting students' reasoning, argumentation, and mathematizing [13].

Several studies reveal that numeracy and financial ability have a close relationship [14-16]. Therefore, this learning design is an alternative design to improve two students' abilities simultaneously, numeracy skills and Islamic financial literacy. This can cover one of the weaknesses of the curriculum in Indonesia, which still does not bring financial literacy to formal education in junior high schools.

\section{CONCLUSION}

We conclude that the ability of Islamic financial literacy, for Islamic boarding school students, can be improved through learning mathematics. Some Islamic financial literacy skills can be promoted including money and shariah transaction, planning and managing finance using shariah product, risk and reward of shariah finance product, and landscape of shariah finance. The MIFL ability can be achieved through a series of learning consisting of 3 activities: identify Islamic financial information, analyze information in an Islamic financial context, and apply Islamic financial knowledge and understanding. Our remarks in the application of this learning design are the aspect of preparing MIFL tasks that students must understand. If there are some terms that students do not understand, then the teacher must add activities that can overcome this in the learning process. In closing, we hope that this learning design will not only help students learn mathematics meaningfully but also as an opportunity to create a caring young generation on the development of Indonesian Islamic economics.

\section{AUTHORS' CONTRIBUTIONS}

Intan Bigita Kusumawat is the research coordinator, conceived the design analysis, conceptualization framework. Achmad Dhany Fachrudin contribute in collected data or analysis tools, and developer of Math-based Islamic financial literacy tasks. Soffil Widadah contribute in manuscript editing, review of developed tasks. Ratu Ilma contribute script reviewer, expert and concept consultant. Zulkardi as expert and concept consultant. M. Khusni Mubarok as director and expert on sharia economics.

\section{ACKNOWLEDGMENTS}

The authors would like to thank the Indonesian Ministry of education, culture research and technology 
(Kemdikbudristek) for supporting this research funding through grant funding with main contract number 167/E4.1/AK.04.PT/2021 and derivative contracts 038 /AMD-SP2H/LT-MULTI-PDPK/LL7/2021.

\section{REFERENCES}

[1] J. K. K. Yeo, Infusing Financial Literacy in Primary Mathematics: A Proposed Framework for Instruction, Singapore: Springer, 2016. DOI: https://doi.org/ 10.1007/978-981-10-0360-8_38

[2] C. Sawatzki, Lessons in financial literacy task design: authentic, imaginable, useful, Mathematics Education Research Journal 29(1) (2017). DOI: https://doi.org/10.1007/s13394-016-0184-0.

[3] OECD, PISA 2018 Assessment and Analytical Framework, OECD publishing, 2019. DOI: https://doi.org/10.1787/b25efab8-en.

[4] C. Pournara, Financial mathematics in the south frican school curriculum, SAARMSTE EXECUTIVE, 312, 2007.

[5] I. Piliyanti, Islamic Economics Education in Indonesia: The Experience of the Sidogiri Islamic Boarding School, Pasuruan, East Java, Jurnal Hukum Islam (JHI) 10(2) (2012). URL: http:e-journal.stainpekalongan.ac.id/index.php/jhi [I. Pilianti, "Pendidikan Ekonomi Islam di Indonesia: Pengalaman Pesantren Sidogiri Pasuruan Jawa Timur," Jurnal Hukum Islam, 2016]

[6] I. B. Kusumawati, A. D. Fachrudin, R. I. I. Putri, Z. Zulkardi, A.W. Kohar, M. K. Mubarok, Islamic financial literacy in mathematics education: A proposed framework (In press).

[7] F. A. M. Nawi, W. M. N. W. Daud, P. L. Ghazali, A. S. Yazid, and Z. Shamsuddin, "Islamic Financial Literacy: A Conceptualization and Proposed Measurement," International Journal of Academic Research in Business and Social Sciences 8(12) (2018). DOI: https:/doi.org/10.6007/IJARBSS/v8-i12/5061.

[8] A. Bakker and D. Van Eerde, An introduction to designbased research with an example from statistics education, Approaches to qualitative research in mathematics education (2015) 429-466. DOI: https://doi.org/10.1007/978-94-017-9181-6_16
[9] K. Gravemeijer and M. Doorman, Context Problems in Realistic Mathematics Education: A Calculus Course as an Example, Educational Studies in Mathematics 39(1) (1999).

DOI: https://doi.org/10.1023/A:1003749919816.

[10] M. van den Heuvel-Panhuizen, The didactical use of models in realistic mathematics education: An example from a longitudinal trajectory on percentage, Educational Studies in Mathematics 54(1) (2003). DOI: https://doi.org/10.1023/B:EDUC.0000005212.03219.d c.

[11] N. A. Aris, R. Othman, R. M. Azli, M. Sahri, D. A. Razak, and Z. A. Rahman, Islamic Banking Products: Regulations, Issues and Challenges, Journal of Applied Business Research (JABR) 29(4) (2013). DOI: https://doi.org/10.19030/jabr.v29i4.7922.

[12] K. Gravemeijer, Local Instruction Theories as Means of Support for Teachers in Reform Mathematics Education Math, Think. Learn 6(2) (2004) 105-128. DOI: https://doi.org/10.1207/s15327833mt10602_3

[13] I. B. Kusumawati, A. D. Fachrudin, R. I. I. Putri, Z. Zulkardi, U. Salmah, and M. K. Mubarok, Designing Mathematics' Tasks to Promote Students' Islamic Financial Literacy (In press).

[14] C. Estrada-Mejia, M. de Vries, and M. Zeelenberg, Numeracy and wealth, Journal of Economic Psychology 54 (2016). DOI: https://doi.org/10.1016/j.joep.2016.02.011.

[15] G. D. Donleavy et al., How numeracy mediates cash flow format preferences: A worldwide study, The International Journal of Management Education 16(2) (2018).

DOI: https://doi.org/10.1016/j.ijme.2018.01.004.

[16] K. Skagerlund, T. Lind, C. Strömbäck, G. Tinghög, and D. Västfjäll, Financial literacy and the role of numeracy-How individuals' attitude and affinity with numbers influence financial literacy, Journal of Behavioral and Experimental Economics 74 (2018). DOI: https://doi.org/10.1016/j.socec.2018. 